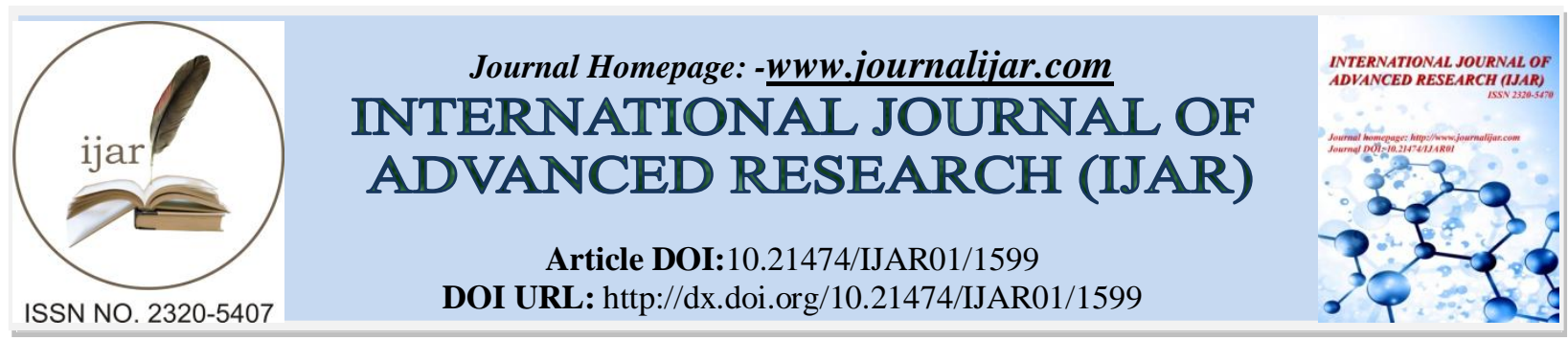

RESEARCH ARTICLE

\title{
EVALUATION OF IN VITRO AND IN VIVO ACTIVITIES OF SOME MEDICINAL PLANTS EXTRACTS AGAINST TRYPANOSOMIASIS.
}

Safaa Mohamed Barghash.

Parasitology Unit, Animal Health Department, Desert Research Center Cairo, Egypt

\section{Manuscript Info}

Manuscript History

Received: 13 June 2016

Final Accepted: 16 August 2016

Published: September 2016

Key words:-

Trypanosoma evansi; Plant extract;

Diminazene aceturate; Antitrypanosomal

activity; Egypt

\section{Abstract}

This study aimed to assess the antitrypanosomal activity of leaf ethanolic extracts against Trypanosoma evansiexperimental infection. Seven medicinal plants: Camellia sinensis, Thymus vulgaris, Menthalongifolia, Azadirachta indica, Oleaeuropoea, Rosmarinus officinalis and Saliva officinalis, were selected based on information from traditional healers on their curative effect against parasites. They were investigated for phytochemical screening and antitrypanosomal properties. Results revealed the presence of saponins, tannins, flavonoids, alkaloids, and phenols. The in vitro antitrypanosomal activity in microtiter plates showed that all of them had pronouncedtrypanocidal effects and inhibited the growth of T. evansi that was observed either disappeared, dissected or non-motile within 10-60 min. of incubation except for $O$. europoea and $R$. officinalis which could not clear the parasites completely. Therefore, only five plants were evaluated for their in vitro extracts administration and in vivo against $T$. evansiexperimental infection. Haematological analysis of the infected and treated rats revealed a marked decline in hemoglobin, hematocrit, total red blood corpuscles, and anaemia persisted until the end of the experimental period. Whereas, the biochemical assay showed increased serum levels of urea, creatinine, aspartate aminotransferase and alanine aminotransferase, total bilirubin, and decreased albumin, globulin, total protein, cholesterol, triglycerol and glucose in some treated groups. We concluded that $S$. officinalis followed by $C$. sinensis possess high antitrypanosomal activity compared to diminazene aceturate, and could be useful in the management of trypanosomiasis. Further study needed to claim and illuminate the phytochemical compounds responsible for this antitrypanosomal activity.

\section{Introduction:-}

Animal trypanosomiasis constitutes one of the major veterinary problems that spread beyond its original distribution in sub-Saharan Africa to North Africa (Atarhouchet al., 2003; Barghash et al., 2014; Omer et al., 2013). One of the important pathogenic trypanosomes in animals is Trypanosoma evansi; the etiological agent of Surrathat is may rapidly fatal or take a chronic course continues for several years in domestic mammals (Vanhollebekeet al., 2006). Trypanocidal drugs constitute the principal method of control, as the development of vaccines against 
trypanosomiasis is still in progress. The current drugs used as veterinary trypanocides include isometamidium chloride, diminazene aceturate, quinapyramine, and cymelarsan. The existing treatments of trypanosomiasis are challenged with problems comprising drug resistance, toxicity and expensive/limited drugs (Atawodi et al., 2002; Legroset al., 2002). Thus, there is an urgent need for new antitrypanosomal drugs that are more effective and safer.

Previous studies reported that some medicinal plants, especially in Africa, have trypanocidal activity due to their flavonoids, alkaloids, and other phytochemicals constituents(Kaboreet al., 2010; Mann et al., 2010).The use of herbal preparations for the treatment of Surra disease still holds a strong potential in that some ethnomedicinal plants have been demonstrated to contain potent trypanocides (Atawodi et al., 2005; Ibrahim et al., 2014; Mbaya and Ibrahim, 2011; Shaba et al., 2012). Several secondary plant metabolites including alkaloids, tannins and anthraquinones have been indicated with trypanocidal activity (Hoppet al., 2004). This presents an urgent need to develop efficacious chemotherapeutic agents from locally available ethnomedicinal plants for use trypanocides. This is the first work had been conducted in Egypt to evaluate the trypanocidal activity of some medicinal plant extracts in compared to diminazene aceturate (DA) and to assess the in vitro and in vivo antitrypanosomal activity for these extracts using rats as a biological model. It was also carried out to assess potential Haematological and biochemical abnormalities that may be associated with the administration of crude leaf ethanol extracts against trypanosomiasis.

\section{Material and Methods:-}

\section{Plant samples collection:-}

The leaves of seven medicinal plants screened: Camellia sinensis, Thymus vulgaris, Menthalongifolia, Azadirachta indica, Oleaeuropoea, Rosmarinus offiicinalis and Saliva offiicinalis. They have collected from different locations on the northern west coastal zone of Egypt except for green tea originated from China was purchased from Libya market at Mersa Matrouh, Egypt (Fig.1). Some of these plants were traditionally used in the treatment of parasitic and microbial diseases. They were identified and confirmed by Taxonomists at Medicinal and Organic Plants Department, Desert Research Center, Egypt, and then investigated for in vitro and in vivo antitrypanosomal activities.

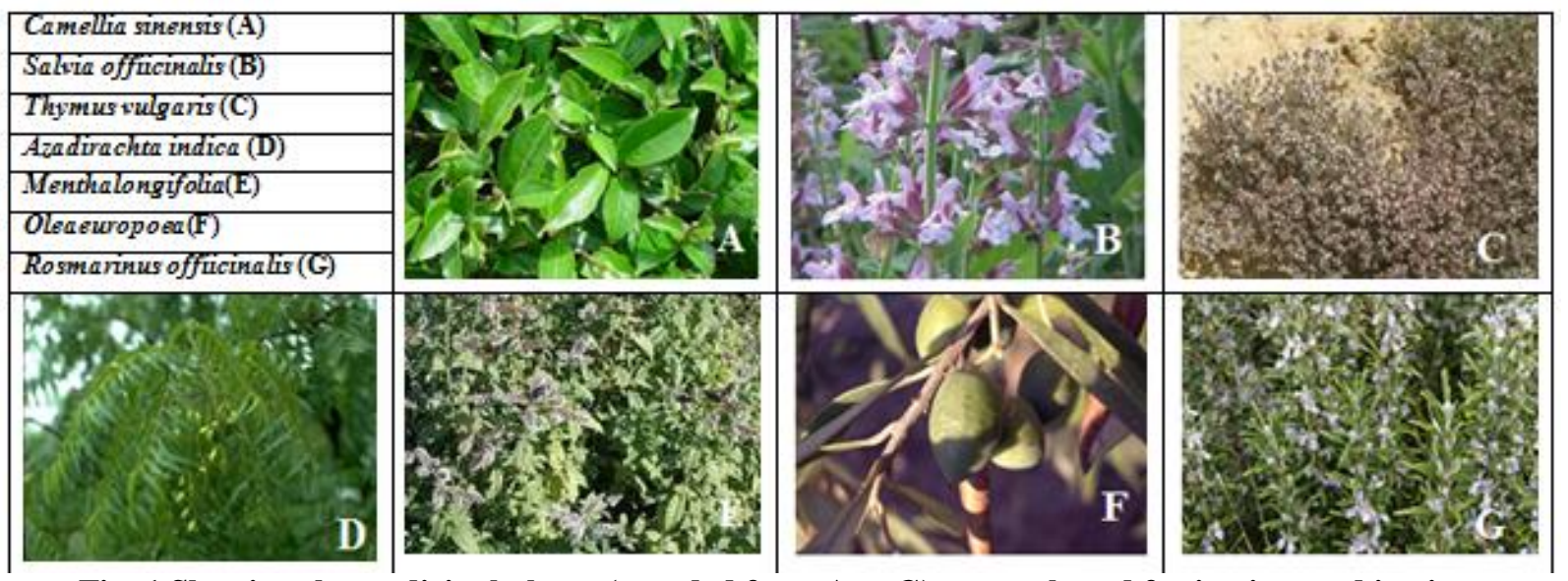

Fig. 1 Showing the medicinal plants (encoded from A to G) were selected for in vitro and in vivo antitrypanosomal activity.

\section{Preparation of Extracts:-}

The leaves of the collected plants were air-dried to a constant weight and grounded into powdered form using an electric blender (Kenwood $\AA$ ). They were extracted by the Soxhlet. The ethanolic extract for each was made by soaking $20 \mathrm{~g}$ of each powdered plant material in a solution of $200 \mathrm{ml}$ of $95 \%$ ethanol, following prior extraction with petroleum ether to de-fat the sample, then filtered using Whatman no. 1 Filter paper. The obtained filtrates were evaporated gently to dryness on a water bath set at $45^{\circ} \mathrm{C}$. The residues were weighed and used for administration by dissolving in Tween $80(0.3 \% \mathrm{v} / \mathrm{v})$, then stored in airtight containers in a refrigerator until required.

\section{Phytochemical Screening of Extracts:-}

The presence of phenols, saponins, tannins, flavonoids and alkaloids in the crude extract were determined according to Parekh et al.(2005). 


\section{Trypanosome propagation:-}

T. evansi was isolated from a naturally infected camel at El-Bassatein abattoir (Cairo, Egypt), then identified and maintained in the laboratory by the continuous passage in white Swiss mice of mixed sexes (20-25 g) to give parasitaemia of approximately $10^{5}$ parasites $/ \mathrm{ml}$. They were infected IP with $0.01 \mathrm{ml}$ of blood containing about $1 \times 10^{3}$ trypanosome cells. The blood film prepared from tail blood at x40 magnification was used as an estimation of parasitaemia. The trypanosome count was determined using the "rapid matching" method of Herbert and Lumsden (1976).

In vitro test for trypanocidal activity of leaf plant extracts:-

Assessment of the in vitro antitrypanosomal activity was performed in triplicates in 96 well microtiter plates (FLOW LABORATORIES INC., MCLEAN, VIRGINIA 22101, USA) according to Atawodi et al., 2009 with some modifications. Approximately, $40 \mu \mathrm{l}$ of blood containing about 50-100 parasites per field was mixed with $10 \mu \mathrm{l}$ of each leaf extract solution of different concentrations $(120,60,30,20,10,5,2,0.5,0.01$ and $0.001 \mathrm{mg} / \mathrm{ml})$. The control was the parasite suspended in $0.3 \%$ Tween 80 only, while the commercial trypanocidal diminazene aceturate (DA) used as a reference. After 5 min incubation at $37^{\circ} \mathrm{C}$, about $5 \mu \mathrm{l}$ of test mixtures were placed on slides and covered with coverslips. The parasites observed every $10 \mathrm{~min}$. for a total duration of sixty minutes. Motility and change in morphology of T. evansi occurred under the microscope (x40) were recorded, and complete elimination of motility or reduction in parasite count was taken as a significant activity of the extracts.

\section{Antitrypanosomal activity of the extracts in rats:-}

Animal model:-

Females Swiss Albino rats (Albino Wister) weighing between200 to 220 gm were purchased from National Research Center, Egypt, and kept in well ventilated plastic cages. They were exposed to 12 hours light and dark cycles fed with pellets and fresh vegetables and watered ad libitum throughout the experimental period. The experiment was conducted in compliance with international accepted principles for laboratory animal use. The rats were allowed a 7-day period of acclimatization before they were divided into groups of ten rats per cage. The weights of the rats were measured before and after treatments till the end of the experiment.

\section{In vitro test for extract administration:-}

Out of seven plants used, only five were selected based on their primarily in vitro antitrypanosomal activity against T. evansi. Eleven different groups with four Swiss Albino rats each was coded and distributed into 11 cages. Ten groups were classified into two groups for each plant at the two most suitable concentrations based on microtiter plates results: one for the minimal dose $\left(\mathrm{LD}_{50}\right)$ that non-motile and significantly reduced $T$. evansi, and the second for the maximal dose $\left(\mathrm{LD}_{90}\right)$ disappeared T. evansi. They were IP administered different extracts at doses of $500 \mu \mathrm{l}$ per week for two successive weeks. The remaining group consisted of the negative control (without leaf extract).

\section{In vivo assay and experimental design:-}

Eight different groups $(\mathrm{n}=10)$ was distributed into 8 cages. Of which, five groups (encoded from A to E) were classified into one group for each selected plant extract at its suitable in vitro concentration and administration. The $\operatorname{six}^{\text {th }}$ group (T) composed of infected but not treated control. These groups were infected with $0.1 \mathrm{~mL}$ of blood from infected mice containing $3 \times 10^{5}$ trypanosomes, were intraperitoneally administered extract at doses of $500 \mu \mathrm{l} /$ $200 \mathrm{gm}$ body weight for two successive weeks, starting a day 5 post infection after the parasites were detected in the blood stream. The seven ${ }^{\text {th }}$ infected group (DA) was given intraperitoneally about of $50 \mu$ (after serial dilution of 0.5 $\mathrm{ml} / 10 \mathrm{Kg}$ body weight) of diminazene aceturate ${ }^{\circ}$ to give reference values. The other group (N-N) maintained an uninfected untreated control.

\section{Therapeutic monitoring of extract:-}

On the seven-day post infection and after two days of extracts and drug administrations, the parasitaemia level of rats in the controls and extracts groups were checked three times a week by wet blood film prepared from tail blood at x40 magnification. Rats were observed daily for clinical signs that included weight loss, edema of the face, ocular discharges, encrustation of the lips, lethargy and mortality rate.Prepatent period, longevity and animal mortality were also observed. The number of parasites seen per field under the microscope was counted and treatment efficacy was determined by the number of rats that did not show clinical signs post-treatment against T. evansi infection. Blood was collected once a week until the end of the experiment for Haematological and biochemical parameters. The whole blood and serum were kept at $-20^{\circ} \mathrm{C}$ for analysis. 


\section{Haematological and biochemical analyses:-}

Every 7 days, $5 \mathrm{~mL}$ blood samples were obtained from each group by heart puncture in two parts with and without anticoagulant, for a period of 42 days. All sera samples were stored at $4^{\circ} \mathrm{C}$ until used. For the hematology analysis, the microhematocrit technique (HCT), red blood cells count (RBCs), total white blood cells count (WBCs), platelets and hemoglobin ( $\mathrm{Hb}$, Drabkin's method) of the whole blood were done manually. Mean corpuscular haemoglobin concentration (MCHC) were calculated from the results obtained from $\mathrm{RBC}, \mathrm{HB}$, and $\mathrm{HCT}$ according to Tornquist (2010). Biochemical analysis was done with fully automated analyzed using commercial kits (SPECTRUM, EGYPT) according to manufacturer's instructions. Liver enzyme (alanine) aminotransferase (ALT), Aspartate aminotransferase (AST), Total protein, Albumin, Globulin, Cholesterol, Glucose level (Liquizyme), Triglyceride (Liquizyme) were estimated as per the instructions of the manufacturer. Serum Creatinine was measured by the Jaffe' method while Urea were estimated by Liquizyme method.

\section{Statistical analysis:-}

Data obtained were expressed as mean \pm standard error of the mean. It was analyzed using SPSS version 20.0 (IBM SPSS Statics 20, USA). Data were subjected to one-way analysis of variance (ANOVA) and the post-hoc test was applied for multiple comparisons. Values of $\mathrm{P}<0.05$ and $\mathrm{P}<0.001$ were regarded as statistically significant and highly significant, respectively.

\section{Results:-}

\section{Phytochemical screening of the ethanol extracts:-}

The results of the phytochemical screening in Table 1 revealed the presence of tannins, saponins, alkaloids, phenols, and flavonoids with different values ranged from high to low. C. sinensis (A) gave high yield, the great valueof tannins, saponins, and phenols, and the least value of alkaloids and flavonoids. Results also showed that $S$. offiicinalis (B) has the least values of tannins and phenols, while Th. vulgaris (C) gave the least value of flavonoids and yield.

\section{In vitro antitrypanosomal activity:-}

Results of thein vitro antitrypanosomal activity of extracts screened in microtiter platesrevealed that all of them showed high activity against $T$. evansi parasites that observed either disappeared, dissected or non-motile within 1045 min. of incubation, except for $\mathrm{F}$ and $\mathrm{G}$ which lasted more time to reduce the parasites at higher concentrations and could not clear the parasites completely. The minimum inhibitory concentration of the extracts from A to Eagainst T. evansi parasites were between $0.001 \mathrm{mg} / \mathrm{ml}$ and $0.01 \mathrm{mg} / \mathrm{ml}$. The standard drug (DA) immobilizes the parasite after 15 minutes, while the control still showed very active motile parasites in $0.3 \%$ Tween 80 at the end of 60 minutes. The motility, reduction, and disappearance of $T$. evansi were directly proportional to the concentrations of the plant extracts. On the other hand, in vitro extracts administrationrevealed that $\mathrm{LD}_{50}$ were 78.5, 26.5, 59.0, 30.0, $40.5 \mathrm{mg} / \mathrm{kg}$ body weight, while $\mathrm{LD}_{90}$ were $300,99.5,102,52.0,150 \mathrm{mg} / \mathrm{kg}$ body weight forplants from A to E, respectively. It also demonstrated that the two selected doses for each plant were safe for rats (Table 1).The combination of these results made $\mathrm{LD}_{90}$ of each plant extract the best option for processing in vivo study.

\section{In vivo antitrypanosomal activity:-}

All T. evansi experimentally infected groups gave parasitaemia of approximately $10^{5}$ parasites $/ \mathrm{ml}$ at day 5 post infection. After extract administrations, groups from A to E showed parasite clearance from $3^{\text {th }}$-day to $11^{\text {th }}$-day posttreatment, except for group B that took two days more to kill $T$. evansithat increased in numbers throughout this time before clearance. At the $22^{\text {th }}$-day post-infection, $T$. evansi were detected and progressed to high numbers for 4 days followed by a reduction in numbers ranged from 1 to 4 trypanosomes/ field before complete disappearance on $30^{\text {th }}$ day post-infection.The parasites returned as non-motile on day 33 then disappeared followed by a relapse, T. evansi were detected in all groups 2 days before the end of the experiment, however, a number of rats in groups D and $\mathrm{E}$ died on the $27^{\text {th }}$ day as a result of reappearance and progress of parasites. The in vivo experiment showed rats infected and not treated (group T), died after $17^{\text {th }}$-day post-infection. In contrast, IP injections of DA at $3.5 \mathrm{mg} / \mathrm{kg}$ body weight (group AD), completely cleared the parasite from the circulation day 1 after the first dose and returned on day 10. The second dose was able to clear the parasites from circulation with prolonging survival period of up to 25 days. Group N-N (not infected not treated) was healthy till the end of the experiment. The extracts of the five plants from A to E exhibited antitrypanosomal effects at $60,20,20,10$ and $30 \mathrm{mg} / 200 \mathrm{gm}$ body weight, respectively (Table 1). 
Table 1:- Phytochemical screening of the seven selected medicinal plants and their yields, names, and in vitro antitrypanosomal activities

\begin{tabular}{|c|c|c|c|c|c|c|c|c|c|c|}
\hline \multirow[t]{2}{*}{$\begin{array}{l}\text { Leaf plant extract } \\
\text { (Code) }\end{array}$} & \multirow[t]{2}{*}{ Family } & \multirow[t]{2}{*}{$\begin{array}{l}\text { Common } \\
\text { name }\end{array}$} & \multirow[t]{2}{*}{ Yield } & \multirow[t]{2}{*}{$\mathbf{K}$} & \multirow[t]{2}{*}{$\mathbf{N}$} & \multirow[t]{2}{*}{$\mathbf{O}$} & \multirow[t]{2}{*}{$\mathbf{S}$} & \multirow[t]{2}{*}{$\mathbf{P}$} & \multicolumn{2}{|c|}{$\begin{array}{l}\text { In vitro } \\
\text { Antitrypanoso } \\
\text { mal activity }\end{array}$} \\
\hline & & & & & & & & & $\mathbf{L D}_{50}$ & $L^{L} D_{90}$ \\
\hline $\begin{array}{l}\text { Camellia sinensis } \\
\text { (A) }\end{array}$ & Theaceae & Green tea & 2.15 & 0.14 & 10.9 & 0.15 & 19.73 & 27 & 78.5 & 300 \\
\hline $\begin{array}{l}\text { Salvia offiicinalis } \\
\text { (B) }\end{array}$ & Lamiaceae & Sage & 1.43 & 0.15 & 2.4 & 0.41 & 7.78 & 5 & 26.5 & 99.5 \\
\hline $\begin{array}{l}\text { Thymus vulgaris } \\
\text { (C) }\end{array}$ & Lamiaceae & Thyme & 0.4 & 0.54 & 7.2 & 0.13 & 7.31 & 8 & 59.0 & 102 \\
\hline $\begin{array}{l}\text { Azadirachta indica } \\
\text { (D) }\end{array}$ & Meliaceae & Neem & 1.33 & 0.20 & 2.9 & 0.24 & 7.59 & 7 & 30.0 & 52.0 \\
\hline $\begin{array}{l}\text { Menthalongifolia( } \\
\text { E) }\end{array}$ & Lamiaceae & Wild mint & 2.44 & 0.30 & 12.45 & 0.24 & 14.81 & 23 & 40.81 & 150 \\
\hline $\begin{array}{l}\text { Oleaeuropoea } \\
\text { (F) }\end{array}$ & Oleaceae & Olive & 1.02 & 0.50 & 7.5 & 0.18 & 20.67 & 21 & \multirow{2}{*}{\multicolumn{2}{|c|}{$\begin{array}{l}\text { Excluded from } \\
\text { in vivo study } \\
\text { due to weak } \\
\text { results(reduced } \\
\text { parasites but not } \\
\text { significant) at } \\
\text { higher } \\
\text { concentrations }\end{array}$}} \\
\hline $\begin{array}{l}\text { Rosmarinus } \\
\text { offiicinalis (G) }\end{array}$ & Lamiaceae & Rosemary & 0.22 & 0.33 & 3.6 & 0.16 & 14.27 & 9 & & \\
\hline
\end{tabular}

Analysis of total alkaloids $(\mathrm{K})$,tannins $(\mathrm{N})$, flavonoids $(\mathrm{O})$, saponins $(\mathrm{S})$ and phenols $(\mathrm{P})$ was $\mathrm{mg} / 100 \mathrm{gm}$, while minimal and maximum lethal doses $\left(\mathrm{LD}_{50}\right.$ and $\left.\mathrm{LD}_{90}\right)$ were $\mathrm{mg} / \mathrm{kg}$ body weight, as they have antitrypanosomal activity against $T$. evansibased on the results ofin vitro micro titer plate and extract administration. Both doses were safe in rats, but only $\mathrm{LD}_{90}$ was used in vivo antitrypanosomal study.

\section{Clinical Observation:-}

Animals of group $\mathrm{T}$ (infected but not treated) exhibited typical clinical signs included oedema in the face, ocular discharges, and the poor condition after experimental infection with $T$. evansistarted from day 5 post-infection. It was significantly higher till death than all treated groups (DA, A-E) and N-N control group. In addition,the weight loss was observed in all infected and treated groups with no significant difference.Anatomically, no significant difference was observed between extracted treated groupsand DA drug treated group. However, different tissues from those groups showed pathological changesin compared to N-N (healthy group). Gross post-mortem examination revealed enlargement of the spleen (splenomegaly) in all groupsexcept group N-N, hemorrhages in lungs (in groups D, E), and very slight enlargement of the liver in the terminal stages of disease just before the end of the experiment. The heart and liver appeared with slight changes in color in all groups, but few abscess were observed only in D group by the end of the fourth week after treatment.

\section{Haematological and biochemical analyses:-}

The RBCs counts were found reduced in infected and treated groups as compared to the healthy group (N-N), while $\mathrm{Hb}$ was found significantly lower $(P<0.05)$ in all infected groups except for group B that within the normal value. The $\mathrm{HCH}$ values were within the normal range in all infected and treated groups except groups $\mathrm{A}, \mathrm{C}, \mathrm{E}$ that significantly decreased $(P<0.05)$. Results of thecalculated MCHC revealed a decrease in infected treated groups and the N-N group without significant differences. On the other hand, WBCs values were within normal range in all control groups (N-N, T, DA) and C treated group, whereas it was significantly higher in groups A, B, D and E than other groups. The platelet's counts were within normal in all groups except for groups DA, A, B, and D that found decreased non-significantly. Results are shown in Table 2. 
Table 2:- Mean \pm Standard Error of the hematological values of experimentally infected and treated groups in compared to control groups in rats.

\begin{tabular}{|l|l|l|l|l|l|l|}
\hline Groups & RBCs & HB & HCT & MCHC & WBCs & PLTs \\
\hline N-N & $7.72 \pm .27^{\mathrm{b}}$ & $15.37 \pm .525^{\mathrm{b}}$ & $47.36 \pm 1.55^{\mathrm{b}}$ & $32.44 \pm .19^{\mathrm{a}}$ & $8.52 \pm 1.05^{\mathrm{abc}}$ & $743.33 \pm 74.71^{\mathrm{a}}$ \\
\hline T & $5.85 \pm .36^{\mathrm{ab}}$ & $11.31 \pm .73^{\mathrm{a}}$ & $35.38 \pm 2.65^{\mathrm{a}}$ & $32.04 \pm .27^{\mathrm{a}}$ & $6.68 \pm .78^{\mathrm{a}, \mathrm{b}}$ & $615.40 \pm 246.70^{\mathrm{a}}$ \\
\hline DA & $6.59 \pm .67^{\mathrm{ab}}$ & $13.34 \pm 1.24^{\mathrm{ab}}$ & $41.02 \pm 3.73^{\mathrm{ab}}$ & $32.50 \pm .07^{\mathrm{a}}$ & $6.41 \pm .89^{\mathrm{a}}$ & $565.10 \pm 99.55^{\mathrm{a}}$ \\
\hline A & $6.64 \pm .78^{\mathrm{ab}}$ & $12.16 \pm .79^{\mathrm{a}}$ & $37.46 \pm 2.37^{\mathrm{a}}$ & $32.44 \pm .06^{\mathrm{a}}$ & $9.20 \pm 1.16^{\mathrm{abc}}$ & $544.00 \pm 83.23^{\mathrm{a}}$ \\
\hline B & $6.88 \pm .75^{\mathrm{b}}$ & $13.86 \pm 1.28^{\mathrm{ab}}$ & $42.63 \pm 3.83^{\mathrm{a}}$ & $32.48 \pm .08^{\mathrm{a}}$ & $11.12 \pm 2.27^{\mathrm{abc}}$ & $565.94 \pm 80.92^{\mathrm{a}}$ \\
\hline C & $6.06 \pm .30^{\mathrm{ab}}$ & $12.36 \pm .59^{\mathrm{a}}$ & $38.11 \pm 1.80^{\mathrm{a}}$ & $32.43 \pm .034^{\mathrm{a}}$ & $6.96 \pm .84^{\mathrm{ab}}$ & $630.60 \pm 110.13^{\mathrm{a}}$ \\
\hline D & $6.43 \pm .03^{\mathrm{ab}}$ & $12.90 \pm .15^{\mathrm{ab}}$ & $39.70 \pm .45^{\mathrm{ab}}$ & $32.49 \pm .01^{\mathrm{a}}$ & $12.91 \pm 3.94^{\mathrm{c}}$ & $587.00 \pm 230.03^{\mathrm{a}}$ \\
\hline E & $4.75 \pm .66^{\mathrm{a}}$ & $11.19 \pm 1.14^{\mathrm{a}}$ & $34.56 \pm 3.43^{\mathrm{a}}$ & $32.34 \pm .10^{\mathrm{a}}$ & $11.81 \pm 2.43^{\mathrm{bc}}$ & $678.50 \pm 90.05^{\mathrm{a}}$ \\
\hline F-test & 2.21 & 2.54 & 2.46 & 1.14 & 2.11 & .30 \\
\hline $\boldsymbol{P}$ value & .061 & .035 & .039 & .365 & .072 & .950 \\
\hline Signe
\end{tabular}

Significant $(\mathrm{P}<0.05)$; highly significant $(\mathrm{p}<0.001)$

Results of biochemical analysis are represented in Table 3 showed high significant differences $(P<o . o o l)$ observed in the levels of glucose, cholesterol, triglyceride, urea, creatinine, ALT, AST, total bilirubin, total protein, albumin, and globulin ranged from high to low in infected and treated groups compared to the control groups. Also, it proved and evidenced that group B has the ideal biochemical values compared with other groups and consequently, the ethanolic plant extract of $S$. offiicinalis is a promising antitrypanosomal medicinal plant against $T$. evansi. It followed by group A that gave values within the range in all parameters except ALT, AST that high increased significantly $(\mathrm{P}<0.001)$, and albumin which slightly decreased. Despite the availability of DA as in vitro and in vivo antitrypanosomal drug, it gave some abnormal high values in urea and ALT, and low levels of albumin. Results also revealed that groups C, D could be used as trypanocidal but not in vivo antitrypanosomal studies.

Table 3:- Mean \pm Standard Error of the biochemical values of experimentally infected and treated groups in compared to control groups in rats.

\begin{tabular}{|c|c|c|c|c|c|c|c|c|c|}
\hline \multirow[t]{2}{*}{ Parameter } & \multicolumn{3}{|c|}{ Control groups } & \multicolumn{5}{|c|}{ Infected and treated groups } & \multirow[t]{2}{*}{ F-test } \\
\hline & $\mathbf{N}-\mathbf{N}$ & $\mathbf{T}$ & DA & A & B & $\mathbf{C}$ & D & $\mathbf{E}$ & \\
\hline Glucose & $\begin{array}{l}122.67 \\
\pm 5.8^{6 \mathrm{c}}\end{array}$ & $\begin{array}{l}66.2 \\
\pm 8.73^{\mathrm{a}}\end{array}$ & $\begin{array}{l}86.6 \\
\pm 4.85^{\mathrm{b}}\end{array}$ & $\begin{array}{l}114.67 \\
\pm 5.67^{\mathrm{c}}\end{array}$ & $\begin{array}{l}117.8 \\
\pm 4.70^{\mathrm{c}}\end{array}$ & $\begin{array}{l}154.4 \\
\pm 3.50^{\mathrm{d}}\end{array}$ & $\begin{array}{l}67.0 \\
\pm 2.74^{\mathrm{a}}\end{array}$ & $\begin{array}{l}65.3 \\
\pm 5.78^{\mathrm{a}}\end{array}$ & 31.2 \\
\hline Cholesterol & $\begin{array}{l}41.17 \\
\pm 1.11^{\mathrm{c}} \\
\end{array}$ & $\begin{array}{l}21.80 \\
\pm 2.71^{\mathrm{a}} \\
\end{array}$ & $\begin{array}{l}30.60 \\
\pm 3.37^{\mathrm{b}} \\
\end{array}$ & $\begin{array}{l}53.00 \\
\pm 1.83^{\mathrm{d}} \\
\end{array}$ & $\begin{array}{l}64.80 \\
\pm .74^{\mathrm{e}} \\
\end{array}$ & $\begin{array}{l}33.0 \\
\pm 3.96^{\mathrm{b}}\end{array}$ & $\begin{array}{l}22.75 \\
\pm 1.11^{\text {a }} \\
\end{array}$ & $\begin{array}{l}103.0 \\
\pm 2.89^{\mathrm{f}}\end{array}$ & 93.0 \\
\hline Triglyceride & $\begin{array}{l}39.83 \\
\pm 5.89^{\mathrm{b}} \\
\end{array}$ & $\begin{array}{l}15.50 \\
\pm 2.00^{\mathrm{a}} \\
\end{array}$ & $\begin{array}{l}21.60 \\
\pm 2.48^{\mathrm{a}}\end{array}$ & $\begin{array}{l}88.00 \\
\pm 5.19^{\mathrm{c}}\end{array}$ & $\begin{array}{l}132.0 \\
\pm 1.10^{\mathrm{e}}\end{array}$ & $\begin{array}{l}23.4 \\
\pm 1.72^{\mathrm{a}}\end{array}$ & $\begin{array}{l}22.75 \\
\pm 3.92^{\mathrm{a}}\end{array}$ & $\begin{array}{l}162.0 \\
\pm 8.51^{\mathrm{a}}\end{array}$ & 150.9 \\
\hline Urea & $\begin{array}{l}20.67 \\
\pm .80^{\mathrm{a}} \\
\end{array}$ & $\begin{array}{l}47.20 \\
\pm 10.30^{\mathrm{c}}\end{array}$ & $\begin{array}{l}26.60 \\
\pm 3.14^{\mathrm{ab}} \\
\end{array}$ & $\begin{array}{l}17.67 \\
\pm 2.11^{\mathrm{a}} \\
\end{array}$ & $\begin{array}{l}13.00 \\
\pm .45^{\mathrm{a}} \\
\end{array}$ & $\begin{array}{l}41.6 \\
\pm 2.21^{\mathrm{c}}\end{array}$ & $\begin{array}{l}36.5 \pm \\
6.85^{\mathrm{bc}}\end{array}$ & $\begin{array}{l}37.7 \pm \\
4.33^{\mathrm{bc}}\end{array}$ & 7.4 \\
\hline Creatinine. & $\begin{array}{l}.36 \\
\pm .01^{\mathrm{a}} \\
\end{array}$ & $\begin{array}{l}1.18 \\
\pm .29^{\mathrm{d}} \\
\end{array}$ & $\begin{array}{l}.57 \\
\pm .05^{\mathrm{ab}} \\
\end{array}$ & $\begin{array}{l}.46 \\
\pm .04^{\mathrm{a}} \\
\end{array}$ & $\begin{array}{l}.32 \\
\pm .01^{\mathrm{a}} \\
\end{array}$ & $\begin{array}{l}.96 \\
\pm .09^{\mathrm{cd}}\end{array}$ & $\begin{array}{l}.64 \pm \\
.07 a b^{c}\end{array}$ & $\begin{array}{l}.93 \\
\pm .15^{\mathrm{bcd}}\end{array}$ & 7.31 \\
\hline ALT & $\begin{array}{l}30.33 \\
\pm 1.98^{\mathrm{a}}\end{array}$ & $\begin{array}{l}112.40 \\
\pm 35.91^{\mathrm{b}}\end{array}$ & $\begin{array}{l}55.80 \\
\pm 8.78^{\mathrm{a}}\end{array}$ & $\begin{array}{l}57.33 \\
\pm 5.31^{\mathrm{a}}\end{array}$ & $\begin{array}{l}30.60 \\
\pm .87^{\mathrm{a}}\end{array}$ & $\begin{array}{l}111.8 \\
\pm 2.38^{\mathrm{b}}\end{array}$ & $\begin{array}{l}70.5 \pm \\
6.06^{\mathrm{ab}}\end{array}$ & $\begin{array}{l}71.0 \\
\pm 6.4^{\mathrm{ab}}\end{array}$ & 5.52 \\
\hline AST & $\begin{array}{l}92.00 \\
\pm 10.2^{\mathrm{ab}}\end{array}$ & $\begin{array}{l}474.0 \\
\pm 133.7^{\mathrm{d}}\end{array}$ & $\begin{array}{l}174.6 \pm \\
25.89^{\mathrm{abc}}\end{array}$ & $\begin{array}{l}192.8 \pm \\
16.4^{\mathrm{abc}}\end{array}$ & $\begin{array}{l}72.60 \pm \\
1.44^{\mathrm{a}} \\
\end{array}$ & $\begin{array}{l}304.0 \pm \\
8.28^{\mathrm{c}}\end{array}$ & $\begin{array}{l}249.8 \pm \\
34.3^{\text {bc }}\end{array}$ & $\begin{array}{l}217.3 \pm \\
21.6^{\mathrm{abc}}\end{array}$ & 6.4 \\
\hline $\begin{array}{l}\text { Total } \\
\text { Bilirubin }\end{array}$ & $\begin{array}{l}.1967 \\
\pm .003^{\mathrm{a}}\end{array}$ & $\begin{array}{l}.2840 \\
\pm .034^{\mathrm{b}}\end{array}$ & $\begin{array}{l}.23 \pm \\
.02^{\mathrm{ab}}\end{array}$ & $\begin{array}{l}.2017 \\
\pm .01^{\mathrm{a}}\end{array}$ & $\begin{array}{l}.18 \pm \\
.004^{\mathrm{a}}\end{array}$ & $\begin{array}{l}.400 \pm \\
.03^{\mathrm{c}}\end{array}$ & $\begin{array}{l}.38 \pm \\
.03^{\mathrm{c}}\end{array}$ & $\begin{array}{l}.280 \pm \\
.05^{\mathrm{b}}\end{array}$ & 14.2 \\
\hline $\begin{array}{l}\text { Total } \\
\text { Protein }\end{array}$ & $\begin{array}{l}5.82 \\
\pm .10^{\mathrm{de}}\end{array}$ & $\begin{array}{l}4.82 \\
\pm .23^{\mathrm{b}}\end{array}$ & $\begin{array}{l}5.24 \\
\pm .25^{\mathrm{bc}}\end{array}$ & $\begin{array}{l}5.50 \\
\pm .13^{\mathrm{cd}}\end{array}$ & $\begin{array}{l}5.98 \\
\pm .04^{\mathrm{e}}\end{array}$ & $\begin{array}{l}4.02 \\
\pm .12^{\mathrm{a}}\end{array}$ & $\begin{array}{l}4.78 \\
\pm .076^{\mathrm{b}}\end{array}$ & $\begin{array}{l}4.87 \\
\pm .07^{\mathrm{b}}\end{array}$ & 18.2 \\
\hline Albumin & $\begin{array}{l}3.72 \pm \\
.09^{\mathrm{a}}\end{array}$ & $\begin{array}{l}2.66 \pm \\
.12^{\mathrm{a}}\end{array}$ & $\begin{array}{l}3.22 \pm \\
.22^{\mathrm{a}}\end{array}$ & $\begin{array}{l}3.58 \\
\pm .14^{\mathrm{b}}\end{array}$ & $\begin{array}{l}3.79 \pm \\
.01 b^{c}\end{array}$ & $\begin{array}{l}2.70 \pm . \\
06 b^{c}\end{array}$ & $\begin{array}{l}2.20 \pm . \\
15 b^{c}\end{array}$ & $\begin{array}{l}3.37 \pm \\
.12^{\mathrm{c}}\end{array}$ & 21.4 \\
\hline Globulin & $\begin{array}{l}2.10 \pm \\
.05^{\mathrm{a}}\end{array}$ & $\begin{array}{l}2.16 \pm \\
.12^{\mathrm{a}}\end{array}$ & $\begin{array}{l}2.02 \pm \\
.05^{\mathrm{b}}\end{array}$ & $\begin{array}{l}1.92 \\
\pm .04^{\mathrm{b}}\end{array}$ & $\begin{array}{l}2.19 \pm \\
.04^{\mathrm{b}}\end{array}$ & $\begin{array}{l}1.32 \pm . \\
07^{\mathrm{b}}\end{array}$ & $\begin{array}{l}2.58 \pm . \\
09^{\mathrm{b}}\end{array}$ & $\begin{array}{l}1.50 \pm . \\
06^{\mathrm{c}}\end{array}$ & 31.1 \\
\hline
\end{tabular}

There is a high significant $(\mathrm{p}<0.001)$ between and within groups at the same horizontal line. 


\section{Discussion:-}

Trypanosomiasis is one of the major parasitic diseases for which control is still far from reality (Toya, 2010). Due to the wide geographic range of Surra that spread beyond its original distribution in Africa, its control has attracted international attention for achieving a decrease in mortality and morbidity using biomedical treatment (Aksoy, 2003; Enwezor and Sackey, 2005).In the present study, the Egyptian selected plants were found to have a strong trypanocidal activity confirmed by in vitro and in vivoantitrypanosomal studies. These plants have been identified belong to Lamiaceaeand Meliaceaefamilies.According to their phytochemical analyses, itrevealed the presence of bioactive compounds such as tannins, saponins, alkaloids, phenols, and flavonoids that may responsible for theirantitrypanosomal activity as reported by Janakiramanet al., 2012.

Many studies have shown that plants within vitro antitrypanosomal activity may have no effect in vivo. To obtain an additional evidence for the antitrypanosomal activity in the current study, we carried out in vitro study for preselection of plants followed by thein vivo study. The in vitro trypanocidal activity of the studied extracts varied from immobilization, reduction and disappeared trypanosomes in corresponding ELISA plate wells. This may be due to these extracts inhibited $T$. evansi exist in higher and lower concentrations levels. Therefore, it is taken as a relatively reliable indicator of the viability of $T$. evansi when compared to the controls and considered promising in theantitrypanosomal screening of crude plant extracts in compliance with Atawodi and Ogunbusola, (2009). The higher value observed for the DA despite its low concentration could be explained by the pure nature of the chemical compound. While plant extracts still crude and impure may lead to antagonistic action of the component compounds in the extracts. Despite this, all crude extracts from A to E exhibited invitro antitrypanosomal activity against $T$. evansi. They were considered most active when inhibited $90 \%$ of parasites before 25 min. of incubation compared with F and $\mathrm{G}$ extracts. Moreover, theextracts administration gave direct evidence for their safety and gave the choice in selecting the suitable concentration for the start in vivo study, in particular; no symptoms of toxicity have occurred for all groups.

In the present study, the reappearance of $T$. evansi on the eleven-day post treatment might be a dose-dependent reduction in the parasitaemia of rats with IP of plant extracts causing the elevation of anaemia and weight loss directly proportional to parasitaemia levels (Coustouet al., 2012). These constant features of trypanosome infections provide information on the severity of the infection. Thesignificant decrease in $\mathrm{HCH}, \mathrm{HB}$, and RBCs values of $T$. evansi infected rats in groups T, A, C, E was in accordance with earlier reports (Faremi and Ekanem, 2011; Oduolaet al., 2010) intrypanosome-infected animals. This may be due to the release of hemolytic factors into the animals blood by dead trypanosomes caused a destruction of erythrocytes and $\mathrm{HB}$, and hence reduction in $\mathrm{HCH}$ (Olukunle et al., 2010). The normal value in $\mathrm{HCH}$ after treatment in groups DA, B, and D may be due to the ability of these extracts to eliminate parasites from the blood (Eghianruwa, 2012; Umar et al., 2007). Anaemia was more severe in control and treated groups except for group B that suffered from slight anaemia as compared to noninfected non-treated rats. It may attribute to intravascularhemolysis as supported by Herrera et al. (2002). The weight loss observed in the infected groups is in agreement with the reports of Abubakaret al. (2005) and Coustou et al. (2012), in which infection with T. evansi was associatedwith weight loss in mice and rats. The significantly increasing of the total leukocytes in all five treated groups (except group C), may be due to the multiplicity of the antigens resulting from morestimulation of immune system (Faremi and Ekanem, 2011) or due to the breakdown of RBCs byphagocytic cells to clean up the toxic remnants of ruptured red blood cells (Olukunleet al., 2010).

Although hypoglycemia is one of the major markers of trypanosomal infection result in increased catabolism of lipids and cholesterol for energy needs (Vigueiraet al., 2012) in groups D and E, no change in glucose levels associated with trypanosomiasis in treated groups. The present study also revealed a decrease in serum lipid caused hyperglyceridemia and hypocholesterolemia in $T$. evansiexperimentally infected rats in some groups. These findings are in agreement with other previous studies (Adam et al., 2009; Balaet al., 2012; Biuet al., 2013) who explained the lowering of the serum triglycerol and cholesterol as a result of trypanosomal continuous utilization of the lipid molecules from the blood stream as an important source of energy. On the other hand, thehyperglyceridemia and hypercholesterolemia in group $\mathrm{E}$ of wild mint may be due to defective plasma triglyceride degradation that probably caused free fatty acid unavailable for importation into hepatocytes despite serum triglyceride elevation (Igbokwe $e t$ al., 2009). The elevated values of enzyme assays ALT and AST activity in the control and treated animals except for groups N-N and B could be attributed to necrosis and inflammation in the liver, heart and kidneys of the host or probably results from host destruction of trypanosomes as previously reported (Abubakaret al., 2005; Takeet and Fagbemi, 2009). In addition, there was a significant difference in the serum albumin, globulin, total bilirubin and total protein of infected and treated animals compared with $\mathrm{N}-\mathrm{N}$ groupcould be due to the difference in the 
antitrypanosomal activities of selected plant extracts in contrary to Hilaliet al., 2006 who reported increase in the total protein during trypanosomiasis. The elevated urea and creatinine levels in the $T$. evansi-infected rats could be due to the destruction of kidney cells resulting in the inability of the kidneys to excrete creatinine during the course of the disease as previously reported (Abd El-Baky and Salem, 2011; Boniface et al., 2011). The increase in bilirubin may be due to hemolytic anaemia or the inability of the liver to conjugate bilirubin as explained by Adeyemiet al. (2012).

Although $M$. longifoliaand $A$. Indicademonstrates a wide range of antibiotic activity against various bacteria, yeasts, and insects and were promising plants have in vitroantitrypanosomal activity in the current study.It has been shown that these plantsare not in vivo safe. It gave fluctuating abnormal biochemical ranged between high and low values. It also raised the liver activity even at the safest doses administered in the rat in agreement with Mikailiet al., 2013.Therefore, these natural insecticides have raisedlevels of liver enzymesthat maycause liver injury, toxicity, and reflect the increase in the severity of liver damage with time as in agreement withBello et al., 2014. In addition, group $\mathrm{E}$ of $M$. longifoliagave cytotoxic high values in all parameters except in albumin and globulin that increased significantly. Administration of the standard drug (DA) and plant extracts of B followed by A prevented the diseaseinduced increases in serum. This may be due to that liver and kidneys could not have been affected at the time of experiment in A and B groups. Some of these findings in the present study are in accordance with the previous reports(Bello et al., 2014; Gutierrez et al.,2013; Muhammad et al., 2013).

\section{Conclusion:-}

In conclusion, this study has established the in vitro and the in vivo antitrypanosomal activity of some medicinal plants, and its potential as a possible drug candidate in the management of trypanosomiasis may be attributed to its high antioxidant activity in spite of the exact mechanism of action is unknown. The data collected indicate that Saliva officinalis can serve as promising antitrypanosomal agent. Further study needed to purify and determine the phytochemical compounds responsible for this antitrypanosomal activity.

\section{Ethical approval:-}

All applicable international, national, and/or institutional guidelines for the care and use of animals were followed.

\section{Acknowledgements:-}

The authorgratefully acknowledges the financial support from the Desert Research Center (DRC), Cairo, Egypt. Also, she would like to thank Mr. Esam Razin, Animal Health Department, DRC, Egypt for statistical analysis.Also, many thanks to Taxonomists at Medicinal and Organic Plants Department, Desert Research Center, Egypt forhelp in plantsidentification.

\section{References:-}

1. Abd El-Baky, AA. and Salem, SI. (2011). Clinicopathological and cytological studies on naturally infected camels and experimentally infected rats with Trypanosoma evansi. World Appl Sci. 14(1): 42-50.

2. Abubakar, A., Iliyasu, B., Yusuf, AB., Onyekwelu, NA., Igweh, AC., Shamaki, BU., Afolayan, DO. and Ogbadoyi, EO. (2005). Antitrypanosomal and Haematological effects of selected Nigerian medicinal plants in Wistar rats. Biokemistri. 17:95-99.

3. Adam, S., Barde N., Abenga, JN., Useh, NM., Ibrahim, NDG. and Esievo, KAN. (2009). Experimental Trypanosoma brucei infection-induced changes in the serum profiles of lipids and cholesterol and the clinical implications in pigs. Cell Anim Biol. 3(2): 15-20.

4. Adeyemi, OS., Akanji, MA. and Ekanem, JT. (2012). Ethanolic extract of Psidiumguajava influences protein and bilirubin levels in Trypanosoma brucei brucei infected rats. J Biol Sci. 12(2):111-116.

5. Aksoy, S., Gibson, WC. And Lehane MJ. (2003). Interactions between tsetse and trypanosomes with implications for the control of trypanosomiasis. Adv Parasitol. 53:1-83.

6. Atarhouch, T., Rami, M., Bendahman, MN. and Dakkak, A. (2003). Camel trypanosomosis in Morocco 1: Results of a first epidemiological survey. Vet Parasitol. 111(4): 277-286.

7. Atawodi, S.E. (2005). Comparative in vitro trypanocidal activities of petroleum ether, chloroform, methanol and aqueous extracts of some Nigerian savannah plants. African J Biotech. 4(2): 177-182. 
8. Atawodi, SE. and Ogunbusola, F. (2009). Evaluation of antitrypanosomal properties of four extracts of leaves, stem and root barks of Prosopisafricana in laboratory animals. Biokemistri. 21(2): 101-108.

9. Atawodi, SE., Ameh, DA., Ibrahim, S., Andrew, JN., Nzelibe, HC., Onyike, E., Anigo, KM., Abu, EA., James, DB., Njoku, GC. and Sallau, AB. (2002). Indigenous knowledge system for treatment of trypanosomiasis in Kaduna state of Nigeria. J Ethnopharmacol. 79(2): 279 - 282.

10. Bala, AY., Adamu, T., Abubakar, U. and Ladan, MJ. (2012). Amelioration of trypanosome-infection-induced alterations in serum cholesterol, triglycerides and proteins by hydro-ethanolic extract of Waltheriaindica in Rats. Res J Parasitol. 6: 127-135.

11. Barghash, SM., Abou El-Naga, TR., El-Sherbeny, EA. and Darwish, AM. (2014). Prevalence of Trypanosoma evansi in Maghrabi camels (Camelus dromedarius) in Northern-West Coast, Egypt using molecular and parasitological methods. Acta Parasitol Glob. 5: 125-132.

12. Bello, AM., Wudil, AM., Muhammad, M., Muhammad, IA., Muhammad, MG. and Al-Khatib, AG. (2014). Toxicological effect of local/ natural insecticides: Seeds of Azadirachta indica, peels of Citrus sinensis and their combination on liver enzymes. European Scientific Journal. 10 (21): 324- 333.

13. Biu, AA., Lawan, BB., Joshua, L., Mohammed, K., Jude, O. and Nelson, OA. (2013). In vitro assessment of trypanocidal activity of aqueous extract of Citrulluslanatus(Cucurbitaceae) (Thunb) leaf and its effects on the haematological parameters of Trypanosoma brucei infected Albino rats.Biokemistri. 25(3): 127-132.

14. Boniface, A., Augustine, I., Ikechukwu, I. and Paschal U. (2011). Prevalence and haemato-biochemical parameters of trypanosome-infected pigs at Nsukka, Nigeria. Comparative ClinPathol. 20(1): 15-18.

15. Coustou, V., Plazolles, N., Guegan, F. and Baltz, T. (2012). Sialidases play a key role in infection and anaemia in Trypanosoma congolense animal trypanosomiasis. Cell Microbiol. 14(3): 431-445.

16. Eghianruwa, KI. (2012). The effect of supplemental antioxidants vitamin $\mathrm{C}$ and dimethylsulfoxide on weight gain and survival in T. brucei infected and diminazene treated rats. VeterinarskiArhiv. 82(5): 519-529.

17. Enwezor, FNC. and Sackey, AKB. (2005). Camel trypanosomosis: a review. Vet Arch. 75:439-452.

18. Faremi, AY. and Ekanem, JT. (2011). Haematological parameters and enzyme studies in Trypanosoma bruceiinfected rats reared on Nigella sativa oil-based diet. Asian J Biochem. 6: 90-97.

19. Gutiérrez, C., González-Martín, M., Corbera1, AJ. and Tejedor-Junco, MT. (2013). Chemotherapeutic agents against pathogenic animal trypanosomes. Microbial pathogens and strategies for combating them: science, technology and education (A. Méndez-Vilas, Ed.). Formatex. 1564-1573.

20. Herbert, WJ. and Lumsden, WHR. (1976). Trypanosoma brucei: A rapid matching method for estimating the host's parasitaemia. Exp Parasitol. 40: 427- 431.

21. Herrera, HM., Alessi, AC., Marques, LC., Santana, AE., Aquino, LP., Menezes, RF., Moraes, MA. and Machado, RZ. (2002). Experimental Trypanosoma evansi infection in South American coati (Nasuanasua): Haematological, biochemical and histopathological changes.Acta Trop. 81(3): 203-210.

22. Hilali, M., Abdel-Gawad, A., Nassar, A. and Abdel-Wahab, A. (2006). Haematological and biochemical changes in water buffalo calves (Bubalusbubalis) infected with Trypanosoma evansi. Vet Parasitol. 139: 237243.

23. Hopp, KH., Cunningham, LV., Bromel, MC., Schemester, LJ. and Wahba, KSK. (2004). In vitro antitrypanosomal activity of certain alkaloids against Trypanosoma lewisi. Lloydia 39: 375-377.

24. Ibrahim, MA., Mohammed, A., Isah, MB. and Aliyu, AB. (2014). Antitrypanosomal activity of African medicinal plants: A review update. J. Ethnopharmacol. 154: 26-54.

25. Igbokwe, IO., Buratai, LB., Ubah, UL., Aromnde, A. and Igbokwe, NA. (2009). Serum and hepatic lipid levels in rats infected with Trypanosoma brucei. Comp ClinPathol. 18: 191-195.

26. Janakiraman, N., Sahaya, SS. and Johnson, M. (2012). Anti-bacterial studies on Peristrophebicalyculata (Retz.) Nees. Asian Pac J Trop Biomed. 1: 2.

27. Kaboré, A., Tamboura, HH., Traoré, A., Traoré, A., Meda, R., Kiendrebeogo, M., Balem, AMG. and Sawadogo, L. (2010). Phytochemical analysis and acute toxicity of two medicinal plants (Anogeissusleiocarpus and Danielliaoliveri) used in traditional veterinary medicine in Burkina Faso. Arch ApplSci Res. 2(6): 47-52

28. Legros, D., Ollivier, G., Gastellu-Etchegorry, M., Paquet, C., Burri, C., Jannin, J. and Buscher, P. (2002). Treatment of human African trypanosomiasis present situation and needs for research and development. Lancet InfectDis. 2: 437-440.

29. Malebo, HM., Tanja, W., Cal, M., Swaleh, SM., Omolo, MO., Hassanali, A., Sequin, U., Hamburger, M., Brun, R. and Ndiege, IO. (2009). Anti-plasmodial, antitrypanosomal, anti-leishmanial and cytotoxicity activity of selected Tanzanian medicinal plants. Tanzan J Health Res. 11:226-34. 
30. Mann, A., Barnabas, BB. and Daniel, II. (2010). The effect of methanolic extracts of Anogeissusleiocarpus and Terminaliaavicennioides on the growth of some food-borne microorganisms. Aust J Basic Appl Sci. 4(12): 6041-6045.

31. Mbaya, A.W. and Ibrahim, U.I. (2011). In vivo and in vitro activities of medicinal plants on haemic and humoral trypanosomes: A review. Int. J. Pharmacol. 7: 1-11.

32. Mikaili, P., Mojaverrostami, S., Moloudizargari, M. and Aghajanshakeri, S. (2013). Pharmacological and therapeutic effects of MenthaLongifoliaand its main constituent, menthol. Ancient Sci Life. 33:129-36.

33. Oduola, T., Bello, I., Adeosun, G., Ademosun, A., Raheem, G. and Avwioro, G. (2010). Hepatotoxicity and nephrotoxicity evaluation in Wistar albino rats exposed to Morindalucida leaf extract. $N$ Am J Med Sci. 2(5): 230-233.

34. Olukunle, JO., Abatan, MO., Soniran, OT., Takeet, MI., Idowu, OA., Akande, FA., Biobaku, KT. and Jacobs EB. (2010). In vivo antitrypanosomal evaluation of some medicinal plant extracts from Ogun State, Nigeria. Sci World J. 5(10): 17-19.

35. Omar, B., Nezar, A., Khaled, A., Lakhdar, B. and Ammar A. (2013). Trypanosomiasis of camels (Camelus dromedarius) in Algeria: First report. Vet Res Forum. 4(4): 273-275.

36. Parekh, J., Nair, R. and Chanda, S. (2005). Preliminary screening of some folklore medicinal plants from Western India, for potential antimicrobial activity. Indian J of pharmacology. 37: 406-409.

37. Shaba, P., Pandey, NN., Sharma, OP., Rao, JR. and Singh RK. (2012). Antitrypanosomal activity of Piper NigrumL (Black pepper) Against Trypanosoma evansi. J Vet Adv. 2(4): 161-167.

38. Tornquist, SJ. (2010). Hematology of Camelids. In: Weiss, DJ., Wordrop, KJ., editors. Schalm's veterinary haematology. USA: Wiley-Blackwell Publishing Ltd. 910-917.

39. Toya, NB. (2010). Immunobiology of African Trypanosomes: Need of Alternative Interventions. J Biomed Biotech. http://dx.doi.org/10.1155/2010/389153.

40. Umar, AI., Ibrahim, T., Akombum, CA., Nnadi, CJ., Mahdi, MA., Gidado, A. Igbokwe, IO. and Buratai, LB. (2010). The role of intraperitoneally administered vitamin C during Trypanosoma congolense infection of rabbits. Afr J Biotech. 9(32): 5224-5228.

41. Umar, IA., Ogenyi, E. and Okodaso, D. (2007). Amelioration of anaemia and organ damage by combined intraperitoneal administration of vitamin A and C to Trypanosoma brucei brucei infected rat. Afr J Biotech. 6 : 2083-2086.

42. Vanhollebeke, B., Truc, P., Poelvoorde, P., Pays, A., Joshi, PP., Katti, R., Jannin, JG. and Pays, EN. (2006). Human Trypanosoma evansi infection linked to a lack of apolipoprotein L-I. N Engl J Med. 355(26):27522756.

43. Vigueira, PA., Ray, SSb., Martin, BA., Ligon, MM. and Paul, KS. (2012). Effects of the green tea catechin (-)epigallocatechingallate on Trypanosoma brucei. Int J Parasitol Drugs Drug Resistance. 2: 225-229.

44. Worku, M., Franco, R. and Miller, JH. (2009). Evaluation of the activity of plant extracts in Boer Goats. American J Anim Vet Sci. 4 (4): 72-79. 